\title{
Using Cognitive Behavioural Techniques to Improve Academic Achievement in Student-Athletes
}

\author{
Andrea Firth-Clark ${ }^{1}$, Stefan Sütterlin ${ }^{2,3}$ and Ricardo Gregorio Lugo ${ }^{4, *}$ \\ 1 Sport Psychology, University Campus Football Business, London HA9 0WS, UK; A.Firth-Clark@ucfb.com \\ 2 Health and Welfare Sciences, Østfold University College, 2312 Halden, Norway; Stefan.Sutterlin@hiof.no \\ 3 Division of Clinical Neurosciences, Oslo University Hospital, 0372 Oslo, Norway \\ 4 Psychology, Inland Norway University of Applied Sciences, 2418 Elverum, Norway \\ * Correspondence: Ricardo.lugo@inn.no
}

Received: 6 March 2019; Accepted: 22 April 2019; Published: 26 April 2019

check for updates

\begin{abstract}
Improving academic grades within the core areas of English, Science and Mathematics has had a lot of previous research interest, but research has tended to mostly focus on students who are failing, non-athletically talented students or student athletes at collegiate level. The particular needs of athletically talented secondary school students who are academically underperforming have so far been neglected. This study addressed this issue by measuring the outcome of academic grades in these three core areas. Method: During a six week intervention programme, ninety four students were separated into 4 groups: control, heart rate variability biofeedback, performance psychology skills training and a combination of these two interventions. Changes in self-efficacy and self-regulation for all students were also measured. Results: Significant pre-post intervention differences in all academic subjects and generalised self-efficacy were found when compared to the control group. Results also showed that a combination of interventions with medium-large effect size was more effective in improving academic results than the single interventions on their own. All interventions improved self-efficacy, but were not significantly different from each other. Self-efficacy was found not to have any interaction effects. Conclusion: Sport psychological skills training can help student-athletes achieve higher scholastic grades and aid mindfulness intervention. Mindfulness on its own was not found to be the most effective intervention, and as such should be used as an adjunct to other psychological methods. Psychological skills training (PST) may help students generalize approaches used in sport to the academic arena.
\end{abstract}

Keywords: HRV biofeedback; sport interventions; scholastic achievement; self-efficacy

\section{Introduction}

Enabling young people to attain their optimum scholastic level is highly important, as the academic results obtained at this stage affect post-sixteen education and their initial steps onto career pathways [1]. Consequently, performance at this stage is one of the first nationally assessed stages, having far reaching and possibly lifelong consequences for the individual beyond those of the school environment [2]. Consequently, it predicts salary and success in employment [3]. In England, academic progress is measured by nationally recognised qualifications such as the General Certificates of Secondary Education (GCSE) examinations and the Business and Technology Education Council (BTEC) diplomas. Specific subjects such as English and Mathematics hold particular significance as they are 'gateway' topics, meaning students usually cannot progress to higher levels of academia unless they obtain a minimum grade four at GCSE.

The current study is concerned with investigating ways of improving the grades of educationally underperforming, athletically talented, secondary school students at various stages of academic 
preparation for their GCSE examinations. A review of the current literature found that most research involving athletically gifted students focuses on a higher education/collegiate level, and there is a paucity of research focusing on this specific age group, especially within the UK. The interventions used have been shown to aid sporting performance [4-6] and life skills [7]. They have also been used effectively in educational settings when used with student athletes [8]. The current study sought to expand upon existing research and investigate whether student athletes can transfer the mental skills developed from sport performances to academic performances.

Student-athletes have specific challenges that most other students do not have. They must balance their potentially blossoming athletic career with academic demands, but the impact of doing can have both negative and positive consequences. For example, the two roles are often incompatible, resulting in missed lessons in order to accommodate sports training [9] and an enforced choice between reaching their potential in either sport or in education at the expense of the other [10]. The coordination of both academic and sporting requirements, along with their social life and various relationships, can be difficult to manage [11]. Research has found that student athletes have poorer academic results than other students [12], especially in non-sport related subjects [13]. However, contrasting research has found the reverse [9], that there is a positive relationship between academic achievement and physical fitness [14] and that student athletes are more likely to reach their potential in a dual academic and athletic career [15]. Despite these findings, student-athletes have a tendency towards negative self-perceptions [16].

The participants in the current study had been identified by their school gifted and talented programme as having the capacity to do well but were actually underperforming, in that they were below the grades predicted at their current level. The term underperformance, as used here, means students' performances are below that which they have been identified as being able to achieve via standardised academic tests (the CATS and the SATS) taken at the end of key stage two, in the final year of primary school [17]. This means that the student is no longer reaching their termly academic targets set by their secondary school. Each student is compared with the average score for children of their age. These results form the basis by which targets are set for each student and their progress monitored. The performance on SATS, taken aged 11, forms the basis for predicting the student's performance at GCSE level. The overall academic aim of secondary schools is to get as many year 11 students as possible to gain at least five 9-5 grade GCSEs, including English and Mathematics.

In order to investigate ways the targeted students can reach their academic potential, the current study looked at the role of generalised self-efficacy and self-regulation. Generalised self-efficacy is the broad ability to cope in a variety of situations and to be successful in a given task. Self-regulation was examined in terms of enabling the student to increase positive feelings about how well they can control their academic learning experiences. Increasing perceptions of control has been found to augment goal directed behaviours [18]. Such goal-directed behaviour, in turn, raises the positive emotions felt by students in their daily lives [19]. The reason for this is that when students perceived an activity to be valuable and within their control, it was viewed positively and was seen as more enjoyable, which then has the potential to improve learning [20].

\subsection{Self-Efficacy}

Self-efficacy raises the belief individuals have in their ability to complete specific tasks, and directly affects performance outcomes [21], specifically academic performance [22], where it has been shown to predict students' attitude to education [23]. This belief drives action by influencing how hard individuals try to achieve specific tasks, how long they persevere, the effort they extend and their ability to be resilient in overcoming difficulties in order to achieve positive outcomes [24]. Research has demonstrated that self-efficacy is positively related to academic achievement [22-25]. It accounts for eight percent of the variance in academic grades [26]. Hence, it has been shown to be a key predictor of academic performance in the subjects of Science, Mathematics and English [27,28] and Science [29]. 
Self-efficacy can be learned or encouraged, and indicates how students view their potential for future success [30]. As such, it is essential to self-regulation [21,24], to performance and to successful outcomes, especially in education [22,31-33]. Self-efficacy increases academic performance by up to $18 \%$ [34], and is predictive of future academic success [35].

Students high in self-efficacy benefit from being able to persist for longer on a task with increased effort [28] and with higher academic motivation [36]. Increasing self-efficacy therefore aids academic engagement, encourages goal-setting, increases effort, enhances intrinsic motivation and enables the utilisation of available resources [30]. Pertinent to the present study, success increases self-efficacy, and self-efficacy in turn increases the chances of success [28].

In education, self-efficacy has proven to be a consistent predictor of performance outcomes [37]. High general self-efficacy is bound together with higher levels of successful academic performance; predictive qualities of global or general self-efficacy were shown to account for $11.5 \%$ of between-group discrepancy in performance, demonstrating that elevations in self-efficacy scores resulted in improvements in performance amongst undergraduate students [38]. Self-efficacy has also been found to predict science grades [39], but the reported positive association between self-efficacy and science grades was, however, based only on correlational observations, and so does not allow for causal interpretations. In mathematical performance, Bandura [40] found that self-efficacy was also related to the ability to problem solve and adapt to circumstances effectively. The ability to adapt or cope with circumstances is further supported by research indicating general self-efficacy is strongly positively correlated with students' ability to adapt well to academic requirements [41], due to confidence in their ability to cope with the academic demands [38]. The causal relationship between self-efficacy and academic performance has been demonstrated. Although coping self-efficacy has been found to mediate between mindfulness and academic learning [42], it is not known if generalised self-efficacy will also act as a mediating factor between the focused breathing aspect of mindfulness and academic performance. Having highlighted the mechanism of self-efficacy and how these impact on performance, this study further examines generalised self-efficacy as a mediating factor in improving core academic results.

\subsection{Self-Regulation}

Self-regulation is important to performance, and is measured here as it involves individual goal-setting with individuals consciously engaging in behaviour to achieve these goals [43]. It works together with self-correction to keep on track with these goals [44]. It is primarily responsible for the control of attention and the physiological and emotional arousal necessary for goal attainment [45]. Self-regulation is the self's ability to control its own thoughts, emotions and actions, and can predict performance in various domains [46]. A large body of studies have linked self-regulation ability to positive outcomes in academic achievement and learning in both children $[47,48]$ and adolescents [49-51], and have shown that it directly influences goal directed behaviour in education [18] and positive mind-set and emotions [19]. The self-regulation measures used in this study were obtained by the use of a performance profile: a method in which the students identify the self-regulatory criteria important to them by identifying their existing strengths and weaknesses. The performance profile is a tool that aids motivation towards a desired end goal [52]; as such, it is an aid to self-regulation. Performance profiling is based on Personal Construct Theory [53], and the idea that the individual must personally utilise ways of allowing the world to make sense [52]. Performance profiling was used in this study as it allows the participant to communicate the areas of self-regulated learning important to them. Additionally, the study was an intervention based study and interventions to improve self-efficacy should be based on realistic self-assessment by the student [27]. In this instance, self-regulation via performance profiling permits this. It was an important aspect of self-regulation to allow the student to highlight what they considered the most relevant areas involved in learning. This is because self-established goals augment self-reflection, which in turn emphasises the ability to self-manage behaviour conducive to learning [54]. 
The relationship between self-efficacy and self-regulation appears to be two-way, because self-efficacy is malleable and within the control of the student [55]. Thus, it affects self-regulation. It is bi-directional, since self-regulation assists with task mastery and, via motivation, increases effort and problem solving in order to aid the coping mechanisms necessary for good performance. This results in increased persistence in the face of challenges and decreased likelihood of giving up [56]. In short, self-efficacy directly affects self-regulation, and self-regulation impacts on self-efficacy. Furthermore, self-efficacy drives self-regulated learning [57], allowing the student to set academic goals and to favourably perceive their ability to reach these goals.

While a clear relationship exists, and both are related to performance outcomes, specifically in relation to goal direction [58], it has been suggested that self-regulation does not mediate self-efficacy in producing good academic performance [59]. Los [37] concluded that self-efficacy must precede self-regulation, rather than the other way round. Consequently, it was not expected that self-regulation would be a mediating factor. However, a clear link between self-regulation and self-efficacy was expected, with self-efficacy being a mediating factor in the improvement of academic performance. As it remains unclear if self-efficacy mediates self-regulation in assisting good academic outcomes, this study sought to investigate whether self-efficacy is a mediating factor in the relationship between self-regulated learning and academic performance.

Two types of intervention were used to explore ways to improve academic performance in academically underperforming student athletes: a relaxation technique based on focused breathing and heart rate variability training was used, along with a cognitive behaviourally based intervention based on existing sport psychology skills training techniques. The interventions were used alone and in combination to explore the most effective method.

\subsection{Heart Rate Variability Biofeedback (HRVBF)}

Like all meditation practices, mindfulness encompasses an element of focused breathing. Mindfulness is described as the individual obtaining clarity of what is happening within and around them at a specific moment in time [60], also called non-judgemental awareness [61] or present moment experience [62]. However, the dissociation that accompanies non-judgemental awareness can lead to the exacerbation of existing mental health issues. To limit this sort of harm, only fully qualified practitioners should engage in mindfulness training [63]. For this reason, and because focused breathing directly impacts on parasympathetic activity, as well as being central to all meditation practices, only the focused breathing element was used as an intervention in the present study.

Executive functioning is correlated to HRV [64], and cognitive ability is predictive of academic success [65]. When HRV and mindfulness interventions have been used to improve cognitive ability, they elicit similar results [66]. Thus, the use of one over the other should have little effect on the results. While mindfulness has been used in previous research to show scholastic improvement [67-71], with few exceptions [72], little research has been conducted on heart rate variability training in improving cognitive performance, academic performance, self-efficacy or self-regulated behaviour in a secondary school educational context. With regards to the current study, the measures of academic performance involve academic testing in the form of examinations. There is a clear relationship between examination results and anxiety levels in some students [43,73-75]. For those students who do not perform well under examination type assessment due to stress anxiety, relaxation techniques including and diaphragmatic breathing techniques and HRVBF training [76] can aid relaxation while alleviating stress induced anxiety $[77,78]$.

\subsection{Psychological Skills Training (PST)}

Psychological skill training promotes self-regulatory behaviours to enhance performance through several strategies: self-talk, focused attention, goal identification, imagery and cognitive restructuring of outcomes $[79,80]$. PST interventions have been shown to have good effects in different sports: gymnastics [81], high intensity sports [5] and football [82], amongst others. Sport PST programs have 
been used for college student athletes to improve self-esteem (effect size using Cohen $d$ at 0.50 ) and sports confidence (effect size using Cohen $d=0.80$ ) [83], but it is not yet known if such methods are transferrable to academic subjects amongst student athletes. Both HRVBF and PST are targeted at improving the aforementioned self-regulatory and academic skills. HRVBF and PST approaches may have overlapping strategies, but HRVBF is a psychophysiological approach, while PST approaches are more cognitive in nature.

\section{Hypotheses and Aims of the Study}

$\mathbf{H}_{\mathbf{1}}$ : The interventions (HRVBF and sport psychological mental skills training) will improve academic performances.

$\mathbf{H}_{2}$ : The interventions will increase self-efficacy, and predict academic and profile performance (self-regulation) changes.

$\mathbf{H}_{3}$ : The interventions will improve academic performance, self-regulation and self-efficacy, but a combined biofeedback and sport psychology intervention will be more effective than either intervention alone.

$\mathbf{H}_{4}$ : Self-efficacy will mediate the effects of the interventions on academic performance.

The present study examined the effects of different interventions (HRVBF and sport psychological mental skills training) on academic performances. This study also investigated the effects that these interventions have on self-efficacy, and whether self-efficacy interacts with the interventions to predict academic and profile performance (self-regulation) changes. We expected that each intervention would improve academic performance, self-regulation and self-efficacy, but that a combined biofeedback and sport psychology intervention would be more effective than either intervention alone. Given its predictive nature $[27,34,35]$, we also expected that self-efficacy (study 2) would mediate the effects of the interventions on academic performance.

\section{Materials and Methods}

\subsection{Design and Participants}

The participants were recruited from four secondary schools specialising in sports from Southeast London and Kent. The participants $\left(N=94 ; N_{\text {female }}=31\right)$ consisted of a randomised sub-sample of athletically talented secondary school students included on their schools' gifted and talented programmes in academic years 7-11. They were also identified by their school as being academically able but underperforming (i.e., not fulfilling their academic potential) as identified by their SATs and CATS scores, thus they were behind their current academic targets.

The participants represented a variety of sports including swimming $(2.1 \%)$, gymnastics (1\%), football $(49 \%)$, tennis $(5.3 \%)$, netball $(9.5 \%)$, volleyball $(9.5 \%)$, cricket $(4.2 \%)$, athletics $(11.7 \%)$ and rugby $(7.4 \%)$. Participants' sporting ability ranged from good competitive club level to competing at the national level for England. The sample was obtained with the help of the heads of the gifted and talented programmes for each of the schools, who identified participants labelled as gifted in sport by the school but underperforming according to their standard half-termly academic test results in one or more of the three core subjects; English, Mathematics or Science. One hundred and forty-two students in this category were identified by the heads of the schools' gifted and talented (G\&T) programmes as being suitable for this study, and so were invited to take part. Once permission had been given by the school, written participant and parental consent was also sought. A total 123 students originally consented. The data from 94 participants was suitable for inclusion into the study. The data of 19 participants had to be discarded due to poor compliance with experimental procedure. Poor compliance included: not turning up to sessions due to various reasons such as illness, conflicting other activities and forgetfulness, to name but some of the reasons. Some participants frequently came to the sessions too late to adequately complete them, or left the study. Prior to drop out and based on the original 123 participants, the groups were randomly divided (see also Table 1). 
Table 1. Description of interventions.

\begin{tabular}{|c|c|c|c|c|}
\hline & Control $(n=43)$ & $\begin{array}{l}\text { Sport Psychology (SP; } \\
\qquad n=17)\end{array}$ & HRVBF $(n=12)$ & $\begin{array}{l}\text { Combined SP \& } \\
\text { HRVBF }(n=22)\end{array}$ \\
\hline $\begin{array}{l}\text { Intervention } \\
\text { description }\end{array}$ & None & $\begin{array}{l}\text { Trained in focused } \\
\text { breathing with visual } \\
\text { feedback of biomarkers }\end{array}$ & $\begin{array}{l}\text { Training in imagery } \\
\text { techniques, } \\
\text { positive self-talk, } \\
\text { goal setting and } \\
\text { cognitive } \\
\text { restructuring. }\end{array}$ & $\begin{array}{l}\text { Combined HRVBF \& SP } \\
\text { intervention }\end{array}$ \\
\hline Session $* 1$ & \multicolumn{4}{|c|}{$\begin{array}{l}\text { All participants received an introduction to HRV and sport psychology interventions. Including a } \\
\text { question and answer session. Demonstrations of HRV equipment. Explanation of research requirements. }\end{array}$} \\
\hline Session 2 & \multicolumn{4}{|c|}{$\begin{array}{l}\text { Each participant completed the generalised self-efficacy inventory, along with the gifted and talented } \\
\text { questionnaire. }\end{array}$} \\
\hline \multirow[t]{2}{*}{ Session 3 to 9} & $\begin{array}{l}\text { Participants attended a } \\
\text { one-to-one session } \\
\text { which included an } \\
\text { introduction into the } \\
\text { Alive by Somatic } \\
\text { Vision HRV and } \\
\text { biofeedback system. }\end{array}$ & $\begin{array}{l}\text { Eight sessions of } \\
\text { performance enhancement } \\
\text { interventions including } \\
\text { imagery, cognitive } \\
\text { restructuring, anchoring, } \\
\text { positive self-talk, goal } \\
\text { setting and relaxation } \\
\text { techniques. }\end{array}$ & $\begin{array}{l}\text { One session on the } \\
\text { HRV equipment } \\
\text { then eight sessions } \\
\text { of HRV training }\end{array}$ & $\begin{array}{l}\text { Three sessions of HRV } \\
\text { training followed by five } \\
\text { sessions of combined } \\
\text { HRV and sport } \\
\text { psychology/performance } \\
\text { based training. }\end{array}$ \\
\hline & $\begin{array}{l}\text { The participants were } \\
\text { not seen again until the } \\
\text { debrief and testing } \\
\text { session. }\end{array}$ & $\begin{array}{l}\text { After four sessions, } \\
\text { participants were } \\
\text { encouraged to recognize } \\
\text { and utilize transferable } \\
\text { skills from sport to } \\
\text { education. }\end{array}$ & $\begin{array}{l}\text { After four sessions, } \\
\text { participants were } \\
\text { encouraged to } \\
\text { recognize and } \\
\text { utilize transferable } \\
\text { skills from sport to } \\
\text { education. }\end{array}$ & $\begin{array}{l}\text { After five sessions, } \\
\text { participants were } \\
\text { encouraged to recognize } \\
\text { and utilize transferable } \\
\text { skills from sport to } \\
\text { education. }\end{array}$ \\
\hline Session 10 & Debrief and re-testing. & $\begin{array}{l}\text { Debrief and } \\
\text { post-intervention } \\
\text { re-testing }\end{array}$ & $\begin{array}{l}\text { Debrief and } \\
\text { post-intervention } \\
\text { re-testing }\end{array}$ & $\begin{array}{l}\text { Debrief and } \\
\text { post-intervention } \\
\text { re-testing }\end{array}$ \\
\hline
\end{tabular}

* Session one lasted one week. HRVBF $=$ heart rate variability biofeedback.

\subsection{Instruments}

\subsubsection{Self-Regulation}

The self-regulation measures used in this study were obtained by the use of a performance profile: a self-report method in which students determine the self-regulatory criteria important to them. The performance profile is a tool that aids motivation towards a desired end goal [52], and as such it is an aid to self-regulation. Performance profiling allows the participant to communicate the areas of self-regulated learning important to them, and is based upon Personal Construct Theory and the idea that the individual must personally utilise ways of allowing the world to make sense [52].

\subsubsection{Generalised Self-Efficacy Scale—English Version}

This is a self-administered unidimensional, four point Likert scale questionnaire comprising ten items. The items are designed to measure: problem solving ability, motivation and coping ability. Reliability for the generalised self-efficacy scale based on Cronbach's alpha in most studies reaches between 0.75 and 0.91 [84]. Scoring can be summed from 10 to 40, or a mean score can also be used. The current research used a summed score.

\subsubsection{Standardized Academic Tests}

Academic performance was measured by school administered standardised tests in English, Mathematics and Science, conducted once per half term (approximately every six to seven weeks). These results comprised the grades that determined students' performance set against their academic targets. Academic targets are decided by a regression line software analysis which measures the pupil's 
current performance on academic tests based upon the student's baseline score as established by their year six performance in the CATS and SATs academic tests. When the regression lines from schools are compared nationally, it forms the basis for predicting the average progress that should be expected for pupils nationally at specific educational stages. It is against this information that individual student progression is charted and targets set.

\subsection{Process}

After ethical approval had been granted by the University of Greenwich's ethics committee (UREC/10/11.3.5.1), permission was obtained from the head of the gifted and talented (G\&T) programme and head teacher for each of the four secondary schools involved (in the UK, secondary schools cover level two (GSCES or equivalent) and level three (A levels or equivalent) of education. During this stage of education, students range in age between the entry level of year 7 , where students are 11 years of age, to exit level year 13, when students are aged 18. The present study covered years 7 to 11 , i.e., ages 11 to 16, and was concerned with predictions for level two-GSCE or equivalent qualifications). Thereafter, a purposive sample was obtained with the help of the heads of the gifted and talented programme for each of the schools, who identified participants labelled as gifted in sport by the school, but underperforming according to their standard half-termly academic test results, in one or more of the three core subjects: English, Mathematics or Science. A total 142 students in this category were identified by the heads of the schools' G\&T programmes as being suitable for this study, and so were invited to take part in the study. A total 123 originally consented; parental consent and participant assent was gained by all those who agreed to engage with the study. The data of 19 participants had to be discarded due to poor compliance with experimental procedure. Poor compliance included students failing to attend sessions, arriving too late to adequately complete the session and leaving before the session was finished. A further 10 participants after initially agreeing to take part in study dropped out, resulting in the data of 94 participants being used in the study.

The design was a multiple cohort design conducted over the second half of the spring term and the whole of the summer school term. There were a total of 10 sessions (see Table 1).

\subsection{Data Analysis}

Initial power analysis for a $2 \times 3$ factorial ANOVA with four groups was conducted in $G^{*}$ Power to ascertain the minimum required sample size using an alpha of 0.05 , a power of 0.80 and a large effect size $(f=0.40)$ [85]. Based on the aforementioned assumptions, the required sample size was 76. A comparable study also showed a large effect size of 0.80 for sport confidence when using psychological skills training techniques to improve performance outcomes [8].

\section{Results}

\subsection{Academic Results}

The inferential statistics employed in this study included an analysis of nariance (ANOVA) to test for between-group differences, followed by Kruskal-Wallis. To test for pre and post within group differences, a repeated ANOVA was used. To test for correlations between the dependent variables, Spearman $\rho$ correlation was used. Bootstrapping mediation analysis was used to explore any mediating effects of generalised self-efficacy on post intervention results. In order to test normality, the Shapiro-Wilk's test was used. The Kolmogorov-Smirnov test was also used; while not as powerful for testing normality as the Shapiro-Wilk's test, it is adequate for smaller sample sizes.

\subsection{Statistical Analysis}

All variables were checked for normal distribution. Any deviation from normal distribution would lead to the use of non-parametric tests. To test $\mathrm{H}_{1}$, an analysis of variance (ANOVA) was used in order to investigate between-group differences (i.e., type of intervention) of the dependent variables 
(i.e., English, Mathematics and Science results, generalised self-efficacy and performance profile scores). To test within group changes $\left(\mathrm{H}_{2} \& \mathrm{H}_{3}\right)$ of the dependent variables, repeated ANOVAs were used. To test $\mathrm{H}_{4}$, self-efficacy was entered into the regression to check for moderation effects in accordance with Baron and Kenny [86]. Alpha levels were set to 0.05 .

Descriptive Statistics for Changes in Scores after the Intervention for All Measures and for Each Group Can Be Found in Table 2. To test the effects of the different interventions' effects on performance, Levine's test for homogeneity was checked and found to be violated on all factors except for Science score changes. Therefore, non-parametric ANOVA tests (Kruskal-Wallis) were used (see Table 3). Results show that the type of intervention was associated with improved academic performance $\left(\mathrm{H}_{1}\right)$. The interventions were found to increase self-efficacy but not performance profile scores, partially supporting the hypothesis $\left(\mathrm{H}_{2}\right)$.

Table 2. Descriptive statistics of score changes.

\begin{tabular}{cccccc}
\hline \multicolumn{2}{c}{ Intervention Type } & Min & Max & M & SD \\
\hline & English & -10.00 & 4.00 & 0.56 & 2.44 \\
& Maths & -11.00 & 6.00 & 0.44 & 2.88 \\
Control $(n=43)$ & Science & -6.00 & 10.00 & 0.65 & 2.79 \\
& Academic & -3.30 & 5.30 & -0.44 & 1.68 \\
& PP & -30.00 & 23.00 & -5.42 & 8.99 \\
& SE & -2.00 & 5.00 & 0.98 & 1.64 \\
\hline & English & 0.00 & 6.00 & 2.71 & 1.72 \\
& Maths & 0.00 & 6.00 & 2.12 & 1.65 \\
HRVBF $(n=17)$ & Science & 0.00 & 6.00 & 2.00 & 2.45 \\
& Academic & -4.00 & -0.70 & -2.21 & 0.96 \\
& PP & -12.00 & 10.00 & -2.06 & 6.31 \\
& SE & 0.00 & 11.00 & 3.88 & 3.08 \\
\hline \multirow{5}{*}{ SP $(n=12)$} & English & 0.00 & 2.00 & 1.00 & 1.04 \\
& Maths & -2.00 & 6.00 & 2.83 & 2.62 \\
& Science & -4.00 & 6.00 & 1.58 & 2.71 \\
& Academic & -4.00 & 0.70 & -1.86 & 1.61 \\
& PP & -28.00 & 4.00 & -8.92 & 10.62 \\
& SE & -1.00 & 12.00 & 3.25 & 3.70 \\
\hline Combined & English & -2.00 & 6.00 & 3.64 & 2.94 \\
& Maths & -2.00 & 8.00 & 4.27 & 3.40 \\
& Science & 0.00 & 10.00 & 3.64 & 2.19 \\
& Academic & -6.70 & 1.30 & -3.86 & 2.30 \\
& PP & -23.00 & 12.00 & -3.64 & 7.99 \\
& SE & -3.00 & 12.00 & 2.55 & 3.31 \\
\hline
\end{tabular}

$\mathrm{SE}=$ self-efficacy; $\mathrm{PP}$ = performance profile; $\mathrm{HRVBF}$ = heart rate variability biofeedback; $\mathrm{SP}$ = sport psychology.

Table 3. Differences in scores.

\begin{tabular}{ccccccc}
\hline & Control & HRV-BF & SP & HRVBF + SP & $\boldsymbol{H}$ & $\boldsymbol{P}$ \\
\hline English & $0.56(2.44)$ & $2.71(1.72)$ & $1.00(1.04)$ & $3.64(2.94)$ & 20.49 & $>0.001$ \\
\hline Maths & $0.44(2.88)$ & $2.12(1.65)$ & $2.83(2.62)$ & $4.27(3.40)$ & 21.36 & $>0.001$ \\
\hline Science & $0.65(2.79)$ & $2.00(2.45)$ & $1.58(2.71)$ & $3.64(2.19)$ & 19.74 & $>0.001$ \\
\hline Academic & $-0.44(1.68)$ & $-2.21(0.96)$ & $-1.86(1.61)$ & $-3.86(2.30)$ & 34.16 & $>0.001$ \\
\hline PP & $-5.42(2.20)$ & $-2.06(8.99)$ & $8.92(10.62)$ & $3.64(7.99)$ & 4.83 & 0.185 \\
\hline GSE & $0.98(1.64)$ & $3.88(3.08)$ & $3.25(3.70)$ & $2.55(3.31)$ & 14.56 & 0.002 \\
\hline
\end{tabular}

$\mathrm{SE}$ = self-efficacy; $\mathrm{PP}$ = performance profile; $\mathrm{HRVBF}$ = heart rate variability biofeedback; $\mathrm{SP}$ = sport psychology; GSE: General Self-efficacy. 


\subsubsection{Effectiveness of Interventions on Academic Subjects}

To see the effects of the changes within the groups, analyses of variance were used. The most successful results $\left(H_{3}\right)$ were observed when HRVBF and sport psychology interventions were combined, in which condition all four dependent variables (English, Mathematics, Science and the combined results of all three subjects) showed significant improvements in grades (see Table 4). The sport psychology intervention, when compared to the control group, was the next most successful intervention, with significant improvement for the results in Mathematics, combined three core academic subjects and Science. The HRVBF intervention only yielded significant improvements for the combined academic results, and not for any of the individual academic subjects. Although there was no significant difference between the effects of the sport psychology and heart rate variability intervention, the combined intervention seemed to be the most effective intervention for scholastic performance, but the SP intervention had a positive impact on self-efficacy and performance profiling (see Table 3). HRVBF did impact self-efficacy and the individual academic subjects.

Table 4. Effectiveness of interventions on academic subjects ( $p$ value given).

\begin{tabular}{cccccccccccccc}
\hline Subject & $\begin{array}{c}\text { Control vs. } \\
\text { Combined }\end{array}$ & $\eta^{2}$ & $\begin{array}{c}\text { Control vs. } \\
\text { SP }\end{array}$ & $\eta^{2}$ & $\begin{array}{c}\text { Control vs. } \\
\text { HRVBF }\end{array}$ & $\eta^{2}$ & $\begin{array}{c}\text { HRVBF vs. } \\
\text { Combined }\end{array}$ & $\eta^{2}$ & $\begin{array}{c}\text { SP vs. } \\
\text { Combined }\end{array}$ & $\begin{array}{c}\eta^{2} \\
\text { SP vs. } \\
\text { HRVBF }\end{array}$ & $\eta^{2}$ \\
\hline English & $<0.01$ & 0.20 & 0.004 & 0.00 & n.s & 0.18 & 0.320 & 0.00 & n.s & 0.17 & n.s & 0.27 \\
Maths & $<0.01$ & 0.24 & 0.016 & 0.12 & n.s & 0.14 & 0.014 & 0.10 & n.s. & 0.06 & n.s & 0.00 \\
Science & $<0.01$ & 0.30 & n.s & 0.04 & n.s & 0.05 & 0.001 & 0.11 & 0.004 & 0.17 & n.s & 0.00 \\
Combined & $<0.01$ & 0.37 & 0.002 & 0.29 & 0.044 & 0.37 & 0.009 & 0.17 & n.s & 0.20 & n.s & 0.00 \\
Subjects & & & & & & & & & & & & &
\end{tabular}

\subsubsection{Results of Self-Efficacy as a Mediating Factor}

In order to test whether intervention type impacted school performance via generalised self-efficacy $\left(\mathrm{H}_{4}\right)$, multiple mediation analyses were conducted following Baron and Kenny's [86] model between the IV (intervention type) and the DV (academic grades). Self-efficacy did not correlate with any of the dependent variables alone or for any of the intervention types (see Tables 5 and 6), therefore the experimental hypothesis $\left(\mathrm{H}_{4}\right)$ was rejected.

Table 5. Correlations of academic scores, performance profile and self-efficacy.

\begin{tabular}{lccccc}
\hline & $\mathbf{2}$ & $\mathbf{3}$ & $\mathbf{4}$ & $\mathbf{5}$ & $\mathbf{6}$ \\
\hline 1. English & $0.505^{* *}$ & $0.321^{* *}$ & $-0.765^{* *}$ & 0.017 & 0.093 \\
2. Maths & & $0.274^{* *}$ & $-0.809^{* *}$ & -0.086 & 0.142 \\
3. Science & & & $-0.616^{* *}$ & -0.049 & -0.055 \\
4. All academics & & & & 0.015 & -0.100 \\
5. PP & & & & & 0.102 \\
6. GSE & & & & &
\end{tabular}

PP: Performance Profile; GSE: General Self-efficacy. ${ }^{* *}$ Correlation is significant at the 0.01 level (2-tailed).

Table 6. Correlations of the differences in pre- and post-intervention scores on all DVs.

\begin{tabular}{|c|c|c|c|c|c|c|}
\hline Intervention Type & $\begin{array}{l}\text { Difference in Scores } \\
\text { (Pre/Post) }\end{array}$ & 2 & 3 & 4 & 5 & 6 \\
\hline \multirow{6}{*}{ Control } & 1. English & 0.113 & 0.239 & $-0.605^{* *}$ & -0.072 & -0.068 \\
\hline & 2. Maths & & 0.118 & $-0.654^{* *}$ & -0.181 & 0.169 \\
\hline & 3. Science & & & $-0.498^{* *}$ & -0.099 & -0.216 \\
\hline & 4. All subjects & & & & 0.092 & 0.024 \\
\hline & 5. Performance Profile & & & & & 0.140 \\
\hline & 6. General Self-Efficacy & & & & & \\
\hline
\end{tabular}


Table 6. Cont

\begin{tabular}{|c|c|c|c|c|c|c|}
\hline Intervention Type & $\begin{array}{l}\text { Difference in Scores } \\
\text { (Pre/Post) }\end{array}$ & 2 & 3 & 4 & 5 & 6 \\
\hline HRVBF Training & $\begin{array}{l}\text { 1. English } \\
\text { 2. Maths } \\
\text { 3. Science } \\
\text { 4. All subjects } \\
\text { 5. Performance Profile } \\
\text { 6. General Self-Efficacy }\end{array}$ & -0.382 & $\begin{array}{l}-0.296 \\
0.123\end{array}$ & $\begin{array}{c}-0.050 \\
-0.449 \\
-0.719 \text { ** }\end{array}$ & $\begin{array}{c}0.108 \\
-0.023 \\
-0.226 \\
0.174\end{array}$ & $\begin{array}{c}-0.054 \\
-0.316 \\
-0.249 \\
0.434 \\
-0.402\end{array}$ \\
\hline Sport Psychology & $\begin{array}{l}\text { 1. English } \\
\text { 2. Maths } \\
\text { 3. Science } \\
\text { 4. All subjects } \\
\text { 5. Performance Profile } \\
\text { 6. General Self-Efficacy }\end{array}$ & 0.664 * & $\begin{array}{l}0.160 \\
0.092\end{array}$ & $\begin{array}{l}-0.709 \text { ** } \\
-0.770 * * \\
-0.667 *\end{array}$ & $\begin{array}{c}-0.385 \\
-0.323 \\
-0.141 \\
0.326\end{array}$ & $\begin{array}{c}-0.118 \\
0.164 \\
-0.506 \\
0.222 \\
0.053\end{array}$ \\
\hline $\begin{array}{l}\text { Combined HRVBF/Sport } \\
\text { Psychology }\end{array}$ & $\begin{array}{l}\text { 1. English } \\
\text { 2. Maths } \\
\text { 3. Science } \\
\text { 4. All subjects } \\
\text { 5. Performance Profile } \\
\text { 6. General Self-Efficacy }\end{array}$ & $0.908^{* *}$ & $\begin{array}{l}0.215 \\
0.039\end{array}$ & $\begin{array}{l}-0.943^{* *} \\
-0.905^{* *} \\
-0.429^{*}\end{array}$ & $\begin{array}{c}-0.063 \\
0.028 \\
-0.008 \\
-0.015\end{array}$ & $\begin{array}{c}-0.037 \\
-0.073 \\
0.055 \\
0.016 \\
0.333\end{array}$ \\
\hline
\end{tabular}

${ }^{*}$ Correlation is significant at the 0.05 level (2-tailed). ${ }^{* *}$ Correlation is significant at the 0.01 level (2-tailed).

\section{Discussion}

The initial aim of this study was to test the effects of specific interventions and a combination of a sport psychology and HRVBF intervention. The results found that the combined intervention had better results than the control group, but the individual interventions also showed effectiveness. The combined intervention showed significant medium to large effect sizes $\left(\eta^{2}=0.20-0.37\right)$ versus controls, and small to medium effects when compared to HRVBF training $\left(\eta^{2}=0.10-0.17\right)$, while the combined condition was not significantly different than the sport psychology intervention alone. This means that a sport psychology intervention is substantial enough to increase scholastic performance, but if combined with biofeedback training, it could have an interaction effect beyond cumulative effects. All interventions showed large effects when all academic scores where combined, but only the combined condition showed positive results on all dependent variables.

The sport psychology interventions involved several cognitive aspects, and thus played a role in improving academic performance. The HRVBF is similar to mindfulness interventions, with the results of this study supporting the findings of Franco et al. [87], who showed that mindfulness-based interventions improved academic achievement in secondary school students. $\mathrm{Al}$ recent meta-analysis [88] also showed that mindfulness-based interventions had small to medium effects on academic achievement (Hedge's $g=0.40-0.44$ ). The present study also found that the psychology and HRVBF interventions had small to medium effect sizes on academic performance, and, similar to Hedge's finding, we found that when compared to the control group, the HRVBF intervention had a 0.044 effect when the overall results of all three core subjects were combined.

The positive results of the interventions used upon academic performance and self-efficacy can be explained by several factors. First, the sport psychology interventions have overlapping mechanisms with self-regulation strategies, identified by Dembo and Eaton [89] as: goal-setting, self-talk and imagery of consequences, while the sports psychology intervention also included cognitive restructuring. Wolters [90] showed that self-talk, both goal-oriented and efficacy, has positive effects on academic achievement. Imagery was shown to improve academic motivation and to mediate the relationship of performance level and achievement motivation [91]. All interventions showed improvements in self-efficacy, but were not significantly different from each other. This may have been caused by several factors, including placebo effects. Chittaro and Sioni [92] found placebo effects from 
biofeedback on stress measurements (heart rate and electrodermal activity). The fact that all three interventions showed improvements in self-efficacy could also be attributed to the individual qualities of the instructor, who conducted all interventions. Leaders of interventions and groups have been shown to mediate the relationship between participants and performance $[93,94]$.

Some of the overlapping effects of both HRVBF and sport psychology interventions, and the combined intervention, may be due to similar mechanisms in both approaches. Gross's [45] emotion regulation model explains how antecedent regulation strategies (i.e., cognitive restructuring via self-talk or goal identification) are reliant on cognitive control. Both mindfulness based interventions similar to HRVBF and the sport psychology interventions used in this study target cognitive mechanisms that allow for better cognitive control, either directly, or indirectly through focused breathing.

While previous studies have shown that self-efficacy mediates performance $[37,95,96]$, our study did not find such a relationship. While the interventions did improve self-efficacy scores, self-efficacy did not show a reciprocal influence, as stipulated by Bandura [24]. This could be due to the fact that a general self-efficacy score, and not a situational measurement, was used, or that the gains in self-efficacy were not transferred to the academic situation as instructed (see session 3-9 from the intervention description), as also found by Fallah [42]. These interventions were sports-based for student athletes, and these cognitions might not have been generalized, explaining why student athletes may underperform even though they have been cognitively trained otherwise [97]. The no findings from self-efficacy may also explain how Findley \& Bowker [16] described student athletes as feeling less worth than non-student athletes in academic domains, or underperforming academically [12,13]. This underperformance may be due to the inability of the young student-athletes to generalize self-regulatory strategies that are relevant for their sports to more academic and life domains. Future interventions might want to include teaching students how to use sport-specific interventions in areas other than sports, i.e., school or work, that would help them reach higher achievements.

\section{Limitations of the Study}

This experiment has several limitations. First, there were several drop-outs, especially in the HRVBF and SP conditions, that may have affected the results of the study. This also may have affected the distribution of the scores. Non-parametric inferential statistics had to be used due to skewed distributions. General scores for self-efficacy were used. Bandura [24] proposed using more situational measurements of self-efficacy, as it is more predictive. Participants were also from different grade levels (7-11). Individual differences due to developmental stages could influence the final results. The HRVBF group had a disproportionate amount of females (18\%) compared to the other groups $(=>50 \%)$. The effects produced by HRVBF training could be influenced by other factors. Violani \& Lombardo [98] have shown that females are better at learning from biofeedback training, and this was not controlled for in this study. Apart from the initial session and the final session at the end of the experiment, the control group was not exposed to interactions with the researcher to the same extent as those in the test groups. Although this was not a placebo type study, it is possible that the lack of one-to-one interaction with the researcher means that confounds related to dosage cannot be eliminated. Thus, future research should provide the control group with equal one-to-one time engaged with inert activity.

\section{Conclusions}

This study showed that sport-psychology-based interventions can help to improve scholastic performance. A combined intervention, where both biofeedback and self-regulated learning approaches were used, was shown to have positive effects on scholastic achievement and self-efficacy. Contrary to prior studies and models, self-efficacy did not mediate any outcomes, but this may be due to difficulties in generalizing cognitions and skills from one domain to another. Future research and applied interventions should incorporate combined approaches and adjust measurements to more situational rather than general traits. 
Author Contributions: Conceptualization, A.F.; methodology, A.F.; formal analysis, A.F., R.L., S.S.; investigation, A.F.; data curation, A.F., R.L.; writing-original draft preparation, A.F., R.L.; writing-review and editing, A.F., R.L., S.S.; visualization, A.F., R.L.; supervision, S.S, R.L.; project administration, A.F.

Conflicts of Interest: The authors declare no conflict of interest.

\section{References}

1. Attwood, G.; Croll, P.; Fuller, C.; Last, K. The accuracy of students' predictions of their GCSE grades. Educ. Stud. 2013, 39, 444-454. [CrossRef]

2. Isaacs, T. Curriculum and assessment reform gone wrong: The perfect storm of GCSE English. Curric. J. 2014, 25, 130-147. [CrossRef]

3. Kuncel, N.R.; Credé, M.; Thomas, L.L. The validity of self-reported grade point averages, class ranks, and test scores: A meta-analysis and review of the literature. Rev. Educ. Res. 2005, 75, 63-82. [CrossRef]

4. Lagos, L.; Vaschillo, E.; Vaschillo, B.; Lehrer, P.; Bates, M.; Pandina, R. Virtual reality-assisted heart rate variability biofeedback as a strategy to improve golf performance: A case study. Biofeedback 2011, 39, 15-20. [CrossRef]

5. Birrer, D.; Morgan, G. Psychological skills training as a way to enhance an athlete's performance in high-intensity sports. Scand. J. Med. Sci. Sports 2010, 20, 78-87. [CrossRef]

6. Rogerson, L.J.; Hrycaiko, D.W. Enhancing competitive performance of ice hockey goaltenders using centering and self-talk. J. Appl. Sport Psychol. 2002, 14, 14-26. [CrossRef]

7. Carr, C.; Bauman, N. Life skills for collegiate student-athletes. Couns. Coll. Stud. Athl. Iss. Interv. 1996, 2, 281-307.

8. Curry, L.; Maniar, S. Academic course combining psychological skills training and life skills education for university students and student-athletes. J. Appl. Sport Psychol. 2003, 15, 270-277. [CrossRef]

9. Borggrefe, C.; Cachay, K. "Dual careers": The structural coupling of elite sport and school exemplified by the German Verbundsysteme. Eur. J. Sport Soc. 2012, 9, 57-80. [CrossRef]

10. O'Neill, M.; Allen, B.; Calder, A.M. Pressures to perform: An interview study of Australian high performance school-age athletes' perceptions of balancing their school and sporting lives. Perform. Enhanc. Health 2013, 2, 87-93. [CrossRef]

11. Kissinger, D.B.; Miller, M.T. The contemporary college student athlete as a subpopulation. In College Student-Athletes: Challenges, Opportunities, and Policy Implications; Information Age Publishing: Charlotte, NC, USA, 2009; pp. 1-7.

12. Van Rens, F.E.; Elling, A.; Reijgersberg, N. Topsport Talent Schools in the Netherlands: A retrospective analysis of the effect on performance in sport and education. Int. Rev. Sociol. Sport 2015, 50, 64-82. [CrossRef]

13. Shulman, J.; Bowen, W. How the Playing Field Is Encroaching on the Admissions Office. Chron. High. Educ. 2001, 47, B8.

14. De los Mozos Huertas, L.J. Physical Condition and Academic Performance. J. Sport Health Res. 2018, 10, 349-360.

15. Aquilina, D. A study of the relationship between elite athletes' educational development and sporting performance. Int. J. Hist. Sport 2013, 30, 374-392. [CrossRef]

16. Findlay, L.C.; Bowker, A. The link between competitive sport participation and self-concept in early adolescence: A consideration of gender and sport orientation. J. Youth Adolesc. 2009, 38, 29-40. [CrossRef]

17. Ren, K.; Deakin Crick, R. Empowering underachieving adolescents: An emancipatory learning perspective on underachievement. Pedagogies 2013, 8, 235-254. [CrossRef]

18. Mischel, W.; Cantor, N.; Feldman, S. Principles of Self-Regulation: The Nature of Willpower and Self-Control; Guilford Press: New York, NY, USA, 1996.

19. Ketonen, E.E.; Dietrich, J.; Moeller, J.; Salmela-Aro, K.; Lonka, K. The role of daily autonomous and controlled educational goals in students' academic emotion states: An experience sampling method approach. Learn. Instr. 2018, 53, 10-20. [CrossRef]

20. Pekrun, R. The control-value theory of achievement emotions: Assumptions, corollaries, and implications for educational research and practice. Educ. Psychol. Rev. 2006, 18, 315-341. [CrossRef]

21. Bandura, A. Social cognitive theory of self-regulation. Org. Behav. Human Decis. Proces. 1991, 50, $248-287$. [CrossRef] 
22. Choi, N. Self-efficacy and self-concept as predictors of college students' academic performance. Psychol. Sch. 2005, 42, 197-205. [CrossRef]

23. Klassen, R.M.; Usher, E.L. Self-efficacy in educational settings: Recent research and emerging directions. In The Decade Ahead: Theoretical Perspectives on Motivation and Achievement; Emerald Group Publishing Limited: Bingley, UK, 2010; pp. 1-33.

24. Bandura, A. Self-Efficacy: The Exercise of Control; wH Freeman: New York, NY, USA, 1997.

25. Zimmerman, B.J. Attaining self-regulation: A social cognitive perspective. In Handbook of Self-Regulation; Elsevier: Amsterdam, The Netherlands, 2000; pp. 13-39.

26. Chacko, S.; Huba, M. Academic achievement among undergraduate nursing students: The development and test of a causal model. J. Nurs. Educ. 1991, 30, 267-273. [PubMed]

27. Rittmayer, A.D.; Beier, M.E. Overview: Self-efficacy in STEM. SWE AWE CASEE Overv. 2008, 1-12.

28. Schunk, D.H. Self-efficacy and academic motivation. Educ. Psychol. 1991, 26, 207-231. [CrossRef]

29. Andrew, S. Self-efficacy as a predictor of academic performance in science. J. Adv. Nurs. 1998, 27, 596-603. [CrossRef] [PubMed]

30. Bong, M.; Skaalvik, E.M. Academic self-concept and self-efficacy: How different are they really? Educ. Psychol. Rev. 2003, 15, 1-40. [CrossRef]

31. Barrows, J.; Dunn, S.; Lloyd, C.A. Anxiety, self-efficacy, and college exam grades. Univ. J. Educ. Res. 2013, 1, 204-208.

32. Gore, P.A., Jr. Academic self-efficacy as a predictor of college outcomes: Two incremental validity studies. J. Career Assess. 2006, 14, 92-115. [CrossRef]

33. Wilson, K.; Narayan, A. Relationships among individual task self-efficacy, self-regulated learning strategy use and academic performance in a computer-supported collaborative learning environment. Educ. Psychol. Rev. 2016, 36, 236-253. [CrossRef]

34. Komarraju, M.; Nadler, D. Self-efficacy and academic achievement: Why do implicit beliefs, goals, and effort regulation matter? Learn. Individ. Differ. 2013, 25, 67-72. [CrossRef]

35. Hwang, M.H.; Choi, H.C.; Lee, A.; Culver, J.D.; Hutchison, B. The relationship between self-efficacy and academic achievement: A 5-year panel analysis. Asia Pac. Educ. Res. 2016, 25, 89-98. [CrossRef]

36. Schunk, D.H.; Pintrich, P.R.; Meece, J.L. Motivation in Education: Theory, Research, and Applications; Pearson/Merrill Prentice Hall: Upper Saddle River, NJ, USA, 2008.

37. Los, R.E. The Effects of Self-Regulation and Self-Efficacy on Academic Outcome; University of South Dakota: Vermillion, SD, USA, 2014.

38. Lane, J.; Lane, A.M.; Kyprianou, A. Self-efficacy, self-esteem and their impact on academic performance. Soc. Behav. Pers. 2004, 32, 247-256. [CrossRef]

39. Britner, S.L.; Pajares, F. Sources of science self-efficacy beliefs of middle school students. J. Res. Sci. Teach. 2006, 43, 485-499. [CrossRef]

40. Bandura, A. Social cognitive theory of moral thought and action. In Handbook of Moral Behavior and Development; Psychology Press: London, UK, 2014; pp. 69-128.

41. Cordeiro, S.A.; Lobo, C.C.; Coelho, A. Contributos para o Estudo da Relação Entre Bem-Estar Psicológico e Ajustamento Académico. Livro Atas 2016, 148-161.

42. Fallah, N. Mindfulness, coping self-efficacy and foreign language anxiety: A mediation analysis. Educ. Psychol. Rev. 2017, 37, 745-756. [CrossRef]

43. Zeidner, M.; Schleyer, E.J. Educational Setting and the Psychological Adjustment of Gifted Students. Stud. Educ. Eval. 1999, 25, 33-46. [CrossRef]

44. Carver, C.S.; Scheier, M.F.; Weintraub, J.K. Assessing coping strategies: A theoretically based approach. J. Pers. Soc. Psychol. 1989, 56, 267. [CrossRef]

45. Gross, J.J. The emerging field of emotion regulation: An integrative review. Rev. Gen. Psychol. 1998, 2, 271-299. [CrossRef]

46. Jaramillo, J.M.; Rendón, M.I.; Muñoz, L.; Weis, M.; Trommsdorff, G. Children's self-regulation in cultural contexts: The role of parental socialization theories, goals, and practices. Front. Psychol. 2017, 8, 923. [CrossRef]

47. Bohlmann, N.L.; Downer, J.T. Self-regulation and task engagement as predictors of emergent language and literacy skills. Early Educ. Dev. 2016, 27, 18-37. [CrossRef] 
48. Montroy, J.J.; Bowles, R.P.; Skibbe, L.E.; McClelland, M.M.; Morrison, F.J. The development of self-regulation across early childhood. Dev. Psychol. 2016, 52, 1744. [CrossRef]

49. Cetin, B. Academic Motivation and Self-Regulated Learning in Predicting Academic Achievement in College. J. Int. Educ. Res. 2015, 11, 95-106. [CrossRef]

50. Duckworth, A.L.; Seligman, M.E. Self-discipline outdoes IQ in predicting academic performance of adolescents. Psychol. Sci. 2005, 16, 939-944. [CrossRef]

51. Lerner, R.M.; Lerner, J.V.; Bowers, E.P.; Lewin-Bizan, S.; Gestsdottir, S.; Urban, J.B. Self-regulation processes and thriving in childhood and adolescence: A view of the issues. New Dir. Child Adolesc. Dev. 2011, 2011, 1-9. [CrossRef]

52. Butler, R.J.; Hardy, L. The performance profile: Theory and application. Sport Psychol. 1992, 6, $253-264$. [CrossRef]

53. Kelly, G. Personal Construct Psychology; Norton: New York, NY, USA, 1955.

54. Jonker, L.; Elferink-Gemser, M.T.; Tromp, E.; Baker, J.; Visscher, C. The importance of self-regulation. In Routledge Handbook of Sport Expertise; Routledge: Abingdon-on-Thames, UK, 2015; pp. 317-328.

55. Bassi, M.; Steca, P.; Delle Fave, A.; Caprara, G.V. Academic self-efficacy beliefs and quality of experience in learning. J. Youth Adolesc. 2007, 36, 301-312. [CrossRef]

56. Caprara, G.V.; Fida, R.; Vecchione, M.; Del Bove, G.; Vecchio, G.M.; Barbaranelli, C.; Bandura, A. Longitudinal analysis of the role of perceived self-efficacy for self-regulated learning in academic continuance and achievement. J. Educ. Psychol. 2008, 100, 525. [CrossRef]

57. Zimmerman, B.J.; Martinez-Pons, M. Student differences in self-regulated learning: Relating grade, sex, and giftedness to self-efficacy and strategy use. J. Educ. Psychol. 1990, 82, 51. [CrossRef]

58. Reis, S.M.; McCoach, D.B. Underachievement in gifted and talented students with special needs. Exceptionality 2002, 10, 113-125. [CrossRef]

59. Panadero, E.; Jonsson, A.; Botella, J. Effects of self-assessment on self-regulated learning and self-efficacy: Four meta-analyses. Educ. Res. Rev. 2017, 22, 74-98. [CrossRef]

60. Germer, C.; Siegel, R.D.; Fulton, P.R. Mindfulness and Psychotherapy; Guilford Publications: New York, NY, USA, 2016.

61. Kabat-Zinn, J. Wherever You Go, There You Are: Mindfulness Meditation in Everyday Life; Hachette Books: New York, NY, USA, 2009.

62. Creswell, J.D. Mindfulness interventions. Annu. Rev. Psychol. 2017, 68, 491-516. [CrossRef] [PubMed]

63. Lustyk, M.; Chawla, N.; Nolan, R.; Marlatt, G.A. Mindfulness meditation research: Issues of participant screening, safety procedures, and researcher training. Adv. Mind Body Med. 2009, 24, 20-30.

64. Grossmann, I.; Sahdra, B.K.; Ciarrochi, J. A heart and a mind: Self-distancing facilitates the association between heart rate variability, and wise reasoning. Front. Behav. Neurosci. 2016, 10, 68. [CrossRef] [PubMed]

65. Deary, I.J.; Strand, S.; Smith, P.; Fernandes, C. Intelligence and educational achievement. Intelligence 2007, 35, 13-21. [CrossRef]

66. De Bruin, E.I.; van der Zwan, J.E.; Bögels, S.M. A RCT comparing daily mindfulness meditations, biofeedback exercises, and daily physical exercise on attention control, executive functioning, mindful awareness, self-compassion, and worrying in stressed young adults. Mindfulness 2016, 7, 1182-1192. [CrossRef] [PubMed]

67. Frank, J.L.; Jennings, P.A.; Greenberg, M.T. Mindfulness-based interventions in school settings: An introduction to the special issue. Res. Hum. Dev. 2013, 10, 205-210. [CrossRef]

68. Napoli, M.; Krech, P.R.; Holley, L.C. Mindfulness training for elementary school students: The attention academy. J. Appl. School Psychol. 2005, 21, 99-125. [CrossRef]

69. Rosenstreich, E. Mindfulness and memory. In Psychology of Meditation; Singh, N.N., Ed.; Nova: New York, NY, USA, 2014; pp. 167-185.

70. Schonert-Reichl, K.A.; Oberle, E.; Lawlor, M.S.; Abbott, D.; Thomson, K.; Oberlander, T.F.; Diamond, A. Enhancing cognitive and social-emotional development through a simple-to-administer mindfulness-based school program for elementary school children: A randomized controlled trial. Dev. Psychol. 2015, 51, 52. [CrossRef]

71. Song, K.Y.; Muschert, G.W. Opening the contemplative mind in the sociology classroom. Hum. Soc. 2014, 38, 314-338. [CrossRef] 
72. Malinowski, P. Neural mechanisms of attentional control in mindfulness meditation. Front. Neurosci. 2013, 7, 8. [CrossRef]

73. Ahuja, A. A study of self-efficacy among secondary school students in relation to educational aspiration and academic achievement. Educ. Quest 2016, 7, 275. [CrossRef]

74. Gregor, A. Examination anxiety: Live with it, control it or make it work for you? Sch. Psychol. Int. 2005, 26, 617-635. [CrossRef]

75. Wren, D.G.; Benson, J. Measuring test anxiety in children: Scale development and internal construct validation. Anxiety Stress Coping 2004, 17, 227-240. [CrossRef]

76. Henriques, G.; Keffer, S.; Abrahamson, C.; Horst, S.J. Exploring the effectiveness of a computer-based heart rate variability biofeedback program in reducing anxiety in college students. Appl. Psychophysiol. Biofeedback 2011, 36, 101-112. [CrossRef]

77. Larson, H.A.; El Ramahi, M.K.; Conn, S.R.; Estes, L.A.; Ghibellini, A.B. Reducing Test Anxiety among Third Grade Students through the Implementation of Relaxation Techniques. J. Sch. Couns. 2010, 8, n19.

78. Khng, K.H. A better state-of-mind: deep breathing reduces state anxiety and enhances test performance through regulating test cognitions in children. Cognit. Emot. 2017, 31, 1502-1510. [CrossRef]

79. Driskell, J.E.; Copper, C.; Moran, A. Does mental practice enhance performance? J. Appl. Psychol. 1994, 79, 481. [CrossRef]

80. Weinberg, R.; Williams, J. Integrating and implementing a psychological skills training program. Appl. Sport Psychol. Pers. Growth Peak Perform. 2001, 4, 347-377.

81. Fournier, J.F.; Calmels, C.; Durand-Bush, N.; Salmela, J.H. Effects of a season-long PST program on gymnastic performance and on psychological skill development. Int. J. Sport Exercise Psychol. 2005, 3, 59-78. [CrossRef]

82. Thelwell, R.C.; Greenlees, I.A.; Weston, N.J. Using psychological skills training to develop soccer performance. J. Appl. Sport Psychol. 2006, 18, 254-270. [CrossRef]

83. Schwarzer, R.; Jerusalem, M. The general self-efficacy scale (GSE). Anxiety Stress Coping 2010, 12, 329-345.

84. Scholz, U.; Doña, B.G.; Sud, S.; Schwarzer, R. Is general self-efficacy a universal construct? Psychometric findings from 25 countries. Eur. J. Psychol. Assess. 2002, 18, 242. [CrossRef]

85. Erdfelder, E.; Faul, F.; Buchner, A. GPOWER: A general power analysis program. Behav. Res. Methods Instrum. Comput. 1996, 28, 1-11. [CrossRef]

86. Baron, R.M.; Kenny, D.A. The moderator-mediator variable distinction in social psychological research: Conceptual, strategic, and statistical considerations. J. Pers. Soc. Psychol. 1986, 51, 1173. [CrossRef] [PubMed]

87. Franco, C.; Mañas, I.; Cangas, A.J.; Gallego, J. Exploring the effects of a mindfulness program for students of secondary school. Int. J. Knowl. Soc. Res. 2011, 2, 14-28. [CrossRef]

88. Zenner, C.; Herrnleben-Kurz, S.; Walach, H. Mindfulness-based interventions in schools-A systematic review and meta-analysis. Front. Psychol. 2014, 5, 603. [CrossRef]

89. Dembo, M.H.; Eaton, M.J. Self-regulation of academic learning in middle-level schools. Elem. Sch. J. 2000, 100, 473-490. [CrossRef]

90. Wolters, C.A. Regulation of motivation: Evaluating an underemphasized aspect of self-regulated learning. Educ. Psychol. 2003, 38, 189-205. [CrossRef]

91. Vasquez, N.A.; Buehler, R. Seeing future success: Does imagery perspective influence achievement motivation? Pers. Soc. Psychol. Bull. 2007, 33, 1392-1405. [CrossRef]

92. Chittaro, L.; Sioni, R. Affective computing vs. affective placebo: Study of a biofeedback-controlled game for relaxation training. Int. J. Hum. Comput. Stud. 2014, 72, 663-673. [CrossRef]

93. Dionne, S.D.; Yammarino, F.J.; Atwater, L.E.; Spangler, W.D. Transformational leadership and team performance. J. Org. Change Manag. 2004, 17, 177-193. [CrossRef]

94. Vancouver, J.B.; Thompson, C.M.; Williams, A.A. The changing signs in the relationships among self-efficacy, personal goals, and performance. J. Appl. Psychol. 2001, 86, 605. [CrossRef]

95. Multon, K.D.; Brown, S.D.; Lent, R.W. Relation of self-efficacy beliefs to academic outcomes: A meta-analytic investigation. J. Couns. Psychol. 1991, 38, 30. [CrossRef]

96. Stajkovic, A.D.; Luthans, F. Self-efficacy and work-related performance: A meta-analysis. Psychol. Bull. 1998, 124, 240. [CrossRef] 
97. Pajares, F. Self-efficacy beliefs and mathematical problem-solving of gifted students. Contemp. Educ. Psychol. 1996, 21, 325-344. [CrossRef]

98. Violani, C.; Lombardo, C. Peripheral temperature changes during rest and gender differences in thermal biofeedback. J. Psychosom. Res. 2003, 54, 391-397. [CrossRef]

(C) 2019 by the authors. Licensee MDPI, Basel, Switzerland. This article is an open access article distributed under the terms and conditions of the Creative Commons Attribution (CC BY) license (http://creativecommons.org/licenses/by/4.0/). 